\author{
ks. Janusz Królikowski ${ }^{1}$ \\ 0000-0003-3929-6008 \\ Uniwersytet Papieski Jana Pawła II w Krakowie
}

\title{
Najświętsze Serce Jezusa objawieniem, źródłem i pośrednikiem miłosierdzia Bożego
}

Jednym z zagadnień teologiczno-praktycznych, które domaga się obecnie bardziej szczegółowej refleksji teologicznej o charakterze systematycznym, jest zagadnienie wzajemnych relacji, a nawet, można powiedzieć wprost, wzajemnego dopełniania się kultu Najświętszego Serca Jezusa oraz kultu miłosierdzia Bożego. Już zwykła intuicja podpowiada, że nie chodzi tutaj o dwie odrębne formy kultu, ale właściwie o jeden kult, w którego formach wyrazu co najwyżej różnie rozkładają się kładzione akcenty teologiczne. Na tę zbieżność dwu form kultu bardzo jednoznacznie wskazują ich dzieje w Kościele, gdyż w kulcie Najświętszego Serca Jezusa z łatwością i w bardzo szerokim zakresie można znaleźć liczne treści, które dzisiaj zostają co najwyżej wyraźniej uwypuklone w kulcie miłosierdzia Bożego. Wystarczy sięgnąć do encykliki Miserentissimus Redemptor papieża Piusa XI, by zobaczyć, że uwzględnia

\footnotetext{
1 Ks. Janusz Królikowski - prof. dr hab.; kapłan diecezji tarnowskiej; od 2014 roku dziekan Wydziału Teologicznego Sekcja w Tarnowie (UPJPII); teolog dogmatyk, wydawca tekstów źródłowych do dziejów kultury duchowej w Polsce, autor licznych publikacji z tych dziedzin; członek towarzystw naukowych w kraju i za granicą. E-mail: janusz.krolikowski@ upjp2.edu.pl.
} 
ona zagadnienie miłosierdzia Bożego i niejako wstępnie integruje go z kultem Najświętszego Serca Jezusa².

W czasie kanonizacji Faustyny Kowalskiej (30 kwietnia 2000) papież św. Jan Paweł II wyraził syntetycznie ścisły związek zachodzący między Najświętszym Sercem Jezusa i miłosierdziem Bożym: „Poprzez Serce Chrystusa ukrzyżowanego Boże miłosierdzie dociera do ludzi"3. W tym samym kazaniu, komentując słowa z Ewangelii św. Jana mówiące o darze Ducha Świętego udzielonego na odpuszczenie grzechów (J 20, 21-23), papież stwierdził: „Przed wypowiedzeniem tych słów Jezus pokazuje ręce i bok. Pokazuje rany zadane Mu podczas męki, zwłaszcza zranione Serce źródło, z którego wypływa obfity strumień miłosierdzia, rozlewający się na ludzkość. Faustyna Kowalska [...] ujrzy dwie smugi światła promieniu-

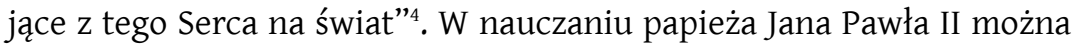
pokazać wiele innych wypowiedzi, w których odzwierciedla się wzajemne przenikanie się i dopełnianie dwóch tajemnic: tajemnicy Najświętszego Serca Jezusa i tajemnicy miłosierdzia Bożego, podobnie zresztą jak jest to widoczne w Dzienniczku św. Faustyny Kowalskiej ${ }^{5}$. Można powiedzieć, że nauczanie św. Jana Pawła II o tych dwóch tajemnicach sytuuje się na linii najbardziej autentycznej tradycji duchowej w Kościele i stanowi także znaczące przypomnienie, aby szczęśliwie rozwijający się kult miłosierdzia Bożego widzieć w ścisłej i bezpośredniej łączności z kultem Najświętszego Serca Jezusa oraz praktycznie łączyć te dwie formy kultu, które tylko we wzajemnej łączności mogą przyczyniać się do odnowy miłości chrześcijańskiej w dzisiejszym świecie i do budzenia nadziei.

2 Por. Pius XI, Enc. Miserentissimus Redemptor (8 maja 1928), w: Serce Jezus $w$ dokumentach Kościoła. Dokumenty Magisterium Kościoła o Najświętszym Sercu Pana Jezusa od Klemensa XIII do Benedykta XVI, zebrał, opracował i wprowadzeniem opatrzył L. Poleszak, Kraków 2006, s. 71-81.

3 Jan Paweł II, Kazanie w czasie mszy św. na placu św. Piotra Dar Boży dla naszych czasów (30 kwietnia 2000 r.), 2, „L'Osservatore Romano” 21 (2000) nr 6, s. 25.

4 Jan Paweł II, Kazanie w czasie mszy św. na placu św. Piotra Dar Boży dla naszych czasów, nr 1.

Por. C. Smuniewski, Święta Faustyna Kowalska - świadek wiary i miłości Najświętszego Serca Jezusa, w: „Świadkowie wiary i miłości Najświętszego Serca Jezusa”. Sympozjum, 14-16 czerwca 2013, red. J. Królikowski, E. Nosiadek, Tuchów 2013, s. 171-193. 
Pojawiające się niekiedy teoretyczne i praktyczne, to znaczy sytuujące się $\mathrm{w}$ dziedzinie pobożności, przeciwstawienia między tymi dwoma rodzajami kultu są zarażone poważnym błędem i nie można nad nimi przejść do porządku dziennego. Pewne różnice zachodzące między tymi dwoma rodzajami kultu w żadnym wypadku nie upoważniają do takiego przeciwstawienia, ale domagają się komplementarnej syntezy, o którą chodzi w niniejszych rozważaniach. Aby ją osiągnąć, trzeba więc dokonać najpierw integracji teologicznej tych dwóch rodzajów kultu, by potem móc zaproponować także ich spójną integrację na poziomie duchowości i pobożności. Tradycja kościelna zwraca naszą uwagę na to, że nie ma żadnej autonomicznej formy kultu, ale autentyczna pobożność i duchowość zakłada, że pojawiające się ich nowe formy będą z wcześniejszymi tworzyły organiczną całość, a zadaniem teologii pozostaje wykazanie właśnie tego faktu, oparte na szukaniu czegoś w rodzaju ich „wewnętrznej wymienności”, gwarantującej ich autentyczność eklezjalną.

Aby w jakiś sposób zbliżyć się do takiej integracji, proponuję w tym miejscu przemyślenie tego, co na temat kultu Najświętszego Serca Jezusa i kultu miłosierdzia Bożego znajdujemy w nauczaniu Jana Pawła II, szczególnie tego zawartego w encyklikach Redemptor hominis (4 marca 1979) i Dives in misericordia (30 listopada 1980). W tych ważnych i ciągle aktualnych dokumentach zawarte są bardzo wyraźne i inspirujące wypowiedzi, pozwalające uchwycić relację zachodzącą między tymi dwoma rodzajami kultu i ich wzajemne dopełnianie się, które może stać się także drogowskazem do ich spójnego połączenia w ramach pobożności chrześcijańskiej. Chodzi o to, by zwłaszcza kultowi miłosierdzia Bożego zapewnić łączność z innymi formami kultu, którego niekiedy zdaje się mu brakować, gdyż jest traktowany zbyt jednostronnie i autonomicznie, co widać choćby w tym, że jest w niejednym przypadku przedstawiany jako jedyna forma kultu i pobożności na nowe czasy. Kult miłosierdzia Bożego można co najwyżej uznać z pewną nową perspektywę, w której można starać się usytuować tradycyjne formy kultu, widząc potrzebę ich zaktualizowania i przystosowania do nowej sytuacji duchowej. 


\section{Tajemnica Serca}

Serce jako przedmiot kultu oznacza wnętrze Pana Jezusa, a szczególnie Jego miłość, co jest zgodne $\mathrm{z}$ antropologią biblijną i z doświadczeniami duchowymi obecnymi w wielu kulturach ${ }^{6}$. Papież Jan Paweł II w swoim nauczaniu mówił wielokrotnie o tajemnicy Serca Jezusa, wskazując tym samym na coś niezwykle głębokiego i ukrytego w Chrystusie, coś, co jest przedmiotem szczególnego objawienia dokonanego za sprawą Ducha Świętego (por. Łk 10, 21-22). Właściwie wszystkie tematy chrystologii i soteriologii pozostają w wyraźnie widocznej relacji do tajemnicy Serca Jezusa, ponieważ wszystkie akty Jego życia wychodzą z Jego najczystszego i przenikniętego boskością wnętrza, którego duchową treść stanowi pełnia wolności (por. Mt 15, 18-20). Podstawowe jednak znaczenie mają te słowa i czyny Pana, które bardziej bezpośrednio odnoszą się do Jego uczuć, a szczególnie do Jego miłości, oraz to wszystko, co odnosi się do najwyższej manifestacji Jego miłości, czyli do Jego absolutnie dobrowolnego i ofiarnego wydania się za nas na krzyżu, abyśmy mieli życie (por. J 15, 13), oraz do mistycznego przedłużania się tego wydania, urzeczywistniającego się nieustannie w Eucharystii, która $\mathrm{w}$ ten sposób zachowuje nierozerwalną łączność z Sercem Jezusa. Efektem tego ostatniego związku i jego przeżywania jest kult Eucharystycznego Serca Jezusa ${ }^{7}$.

Wśród prawd teologicznych, które wprost odnoszą się do tajemnicy Serca Jezusa w sobie i jako przedmiotu kultu w Kościele i w naszej pobożności, można wyliczyć następujące: centralne miejsce Jezusa Chrystusa w zbawczym zamyśle Bożym, autentyczność i realizm wcielenia, czyli faktu, że wieczny Syn Boży stał się prawdziwie człowiekiem oraz że stał się nim dla nas i dla naszego zbawienia (jest Zbawicielem wszystkich i każdego w jego całości). Miłość Odkupiciela jest miłością w najwłaściwszym znaczeniu, a jest to miłość w pełni Boska i miłość miłosierna

6 Por. O. M. Høystad, Serce. Historia kultury i symbolu, tłum. M. Gołębiewska-Bijak, Warszawa 2011.

7 Por. B. de Margerie, Histoire doctrinale du culte envers le Coeur de Jésus, t. 2: L'amour devenu Lumière(s), Paris 1995, s. 223-252. 
wobec grzesznika, nosząca także wszystkie rysy miłości ludzkiej pełnej i dojrzałej, dlatego nie wahamy się podkreślać w soteriologii, że wcielony Syn Boży „umiłował nas ludzkim Sercem”. Chrystus jest naszym pojednaniem i naszym zadośćuczynieniem za pośrednictwem swojej ofiary miłości złożonej na krzyżu Ojcu, która w Jego zmartwychwstaniu objawiła się jako miłość zwycięska. On jest sprawiedliwością i miłością Bożą, On jest „naprawicielem” człowieka i natury ludzkiej. Z tej racji misterium paschalne stanowi najbardziej właściwą podstawę kultu Najświętszego Serca Jezusa jako kultu miłości Bożej’.

Chrystus jest głową ciała, którym jest Kościół, a który jest budowany przez sakramenty, przede wszystkim przez Eucharystię, z której wypływa całe jego życie i moc w pełnieniu jego posłania zbawczego w dziejach na rzecz ludzkości. Dlatego zarówno liturgia kościelna, jak i wypowiedzi doktrynalne podkreślają, że „z boku Chrystusa umierającego na krzyżu zrodził się przedziwny sakrament całego Kościoła” ${ }^{10}$. Chrześcijanie za pośrednictwem Kościoła uczestniczą w misji kapłańskiej i odkupieńczej Chrystusa, jeśli na Jego miłość odpowiadają swoją miłością, konkretyzując ją między innymi w postawie wstawiennictwa za grzeszników i wynagrodzenia za grzechy popełnione ${ }^{11}$. Soteriologia wynagrodzenia, która ściśle łączy się z kultem Serca Jezusa, jest jak najbardziej spójna z całością soteriologii chrześcijańskiej i odznacza się zasadniczą spójnością z faktem, że Chrystus jest „ofiarą przebłagalną za nasze grzechy” (1 J 4, 10). Ta miłość jest naszym wydaniem się dla Chrystusa i naszą służbą na rzecz innych ludzi w duchu chrześcijańskiego miłosierdzia, zakorzeniającego się w głębi naszego serca.

8 II Sobór Watykański, konst. Gaudium et spes, 22.

9 Por. J. Ratzinger, Tajemnica wielkanocna - najgłębsza treść i podstawa kultu Serca Jezusowego, w: J. Ratzinger, Jezus z Nazaretu. Studia o chrystologii, tłum. W. Szymona, Lublin 2015, s. 615-631 (Opera Omnia, t. VI/2).

10 II Sobór Watykański, konst. Sacrosanctum Concilium, 5; K. Rahner, E latere Christi. Der Ursprung der Kirche als zweiter Eva aus der Seite Christi des zweiten Adam. Eine Untersuchung über den typologischen Sinn von Joh 19,34, w: K. Rahner, Spiritualität und Theologie der Kirchenväter, Düsseldorf-Freiburg i. Br. 1999, s. 1-84 (Sämtliche Werke, 3).

11 Szerokie perspektywy zagadnienia zostały zaprezentowane w: W misji wynagrodzenia Bogu przez Serce Jezusa. Materiały z sympozjum naukowego poświęconego kultowi Serca Jezusowego, Lublin 2 października 2014 roku, red. J. Wełna, E. Ziemann, Kraków 2015. 
Można więc powiedzieć, że Serce Jezusa jest wielką „syntezą” dziejów zbawienia i szkołą nowego życia, formującą nowego człowieka na miarę każdych czasów. Ono jest całością dogmatu i życia Kościoła, a więc Ono jest naszym zbawieniem i naszym kresem. Wszystko, co urzeczywistnia się w odniesieniu do Serca Jezusa, ostatecznie wypełni się też w Jego Sercu. Kult Serca Jezusa ma zatem cechy syntetyzujące doświadczenie chrześcijańskie i spójnie je ukierunkowuje chrystologicznie i teocentrycznie, a tym samym spójnie prowadzi je do wypełnienia egzystencjalnego.

\section{Boski wymiar odkupienia}

W encyklice Redemptor hominis papież Jan Paweł II zwrócił bardzo mocno uwagę na potrzebę spojrzenia na tajemnicę odkupienia w świetle jej boskiego wymiaru ${ }^{12}$. Należy to podkreślić z tej racji, że teologia XX wieku bardzo jednostronnie skoncentrowała się na ludzkim wymiarze odkupienia, czerpiąc inspiracje z tzw. zwrotu antropologicznego, a tym samym obniżyła rangę odkupienia w ogóle ${ }^{13}$. W perspektywie wskazanej w encyklice Redemptor hominis Chrystus na pierwszym miejscu jest więc Synem Bożym, który - pojednując nas z Ojcem i dokonując za nas zadośćuczynienia wiecznej miłości Ojca, którą człowiek odrzucił i stale odrzuca przez swój grzech - dokonał odkupienia, potwierdzając i odnawiając wieczną wierność Boga w stosunku do człowieka, tę wierność, która oczywiście nie cofa się wobec wymogów sprawiedliwości Bożej, ale łaskawie poszerza się na miłość i miłosierdzie. Jan Paweł II pisze więc tak: „Odkupienie świata - owa wstrząsająca tajemnica miłości, w której niejako na nowo «powtarza się» tajemnica stworzenia - jest w swoim najgłębszym rdzeniu «usprawiedliwieniem» człowieka w jednym ludzkim Sercu: w Sercu Jednorodzonego Syna, ażeby mogło ono stawać się sprawiedliwością serc

12 Por. W. Hryniewicz, W głąb tajemnicy odkupienia. Doniosłość soteriologicznej nauki Jana Pawła II, w: Jan Paweł II, Redemptor hominis. Tekst i komentarze, red. Z. Zdybicka, Lublin 1982, s. 173-195 (Jan Paweł II Naucza, 5).

13 Por. J. Ratzinger, Odkupienie - coś więcej niż frazes, w: J. Ratzinger, Jezus z Nazaretu. Studia o chrystologii, dz. cyt., s. 863-872. 
tylu ludzi, w tym Przedwiecznym Jednorodzonym Synu przybranych odwiecznie za synów i wezwanych do Łaski, wezwanych do Miłości” (nr 9).

Papież Jan Paweł II używa w tej wypowiedzi słowa „sprawiedliwość” w takim sensie, w jakim używa go św. Paweł w swoich pismach, czyli wskazuje na sprawiedliwość zbawczą, która pochodzi od Boga i której człowiek potrzebuje w najwyższym stopniu. Dotyczy to zarówno życia wiecznego człowieka, jak i życia doczesnego. Chodzi więc zasadniczo o uporządkowanie relacji między Bogiem i człowiekiem, którego dokonuje Chrystus, będący osobowo „sprawiedliwością Bożą” (1 Kor 1, 30). Człowiek, który przez grzech odrzucił ojcostwo Boże, składa teraz pełne zadośćuczynienie tej miłości Ojcowskiej nie za pośrednictwem swoich ograniczonych sił i swoich dzieł, ale w absolutnie świętym Synu, który stał się prawdziwym człowiekiem i jest Pierworodnym między wielu braćmi. Odsłania się tutaj wielka tajemnica pośredniczenia między Bogiem i człowiekiem, której urzeczywistnienie wziął na siebie Syn Boży, gdyż tylko On mógł ją urzeczywistnić, przyjmując ludzkie ciało i w nim pełniąc misję pośredniczenia ${ }^{14}$.

Dwie uwagi mogą nam pomóc dowartościować tę wypowiedź zaczerpniętą z encykliki Jana Pawła II, która wskazuje na Serce Jednorodzonego Syna jako źródło sprawiedliwości dla wszystkich ludzi. Przede wszystkim przychodzi na myśl tekst św. Pawła dotyczący Chrystusa jako źródła sprawiedliwości dla wszystkich grzeszników: „Czyn sprawiedliwy Jednego sprowadza na wszystkich ludzi usprawiedliwienie dające życie" (Rz 5, 18). To, co św. Paweł mówi o Chrystusie, encyklika Redemptor hominis stwierdza o Sercu Jednorodzonego Syna. Jest to najbardziej centralne usytuowanie Serca Jezusa w odniesieniu do dokonanego przez Niego dzieła odkupienia. Pokazuje ono mianowicie, że Serce Jezusa jest Sercem dla wszystkich, a jego dzieło jest uniwersalne.

Druga uwaga odnosi się do znaczenia słowa „serce” zastosowanego w encyklice. Serce ma znaczenie cielesne, ponieważ jest częścią ciała ludzkiego. Papież mógł wyrazić tajemnicę wcielenia za pośrednictwem tego sugestywnego i nośnego teologicznie zdania: „Tajemnica

14 Por. V. Battaglia, Gesù Cristo, luce del mondo. Manuale di cristologia, Roma 2007, s. 321354 (Bibliotheca - Manualia, 4). 
ta ukształtowała się poniekąd pod sercem Dziewicy z Nazaret, gdy Ona wypowiedziała swoje «fiat»" (nr 22). Gdy mówimy jednak o sercu, nie możemy zatrzymać się na znaczeniu cielesnym tego słowa. Ograniczenie się do tego aspektu byłoby zubożeniem wielorakich znaczeń tego słowa. Papież Jan Paweł II w swojej encyklice odwołuje się do słowa „serce” jako do głębokiej rzeczywistości ontologicznej i świadomości ludzkiej, jako „wewnętrznej tajemnicy człowieka” (nr 8). Serce - symbol rzeczywisty i pierwotny, jak wielokrotnie podkreślał zwłaszcza Karl Rahner w swoich wypowiedziach na temat teologii Serca Jezusa ${ }^{15}$ - wyraża więc syntetycznie i symbolicznie osobę w jej wewnętrznej głębi, w samym jej centrum duchowym, w jej wolności i w jej dążeniach. Zwrócić się do Serca Jezusa oznacza iść do Niego, do Jego wewnętrznej i fascynującej tajemnicy, a przede wszystkim do Jego bosko-ludzkiej wolności, z której rodzi się i którą się kieruje Jego miłość odkupieńcza, która z Jego Serca opromienia całą Jego osobę, każdy dokonywany wybór i każdy spełniany czyn, których On dokonuje w swoim życiu, czyniąc je całe tajemnicą zbawienia. W najwyższym stopniu odnoszą się te uwagi do kapłańskiej ofiary Chrystusa, w której najdoskonalej wyraziła sięJego wolność i Jego miłośćc ${ }^{16}$.

Papież Jan Paweł II w tekście encykliki Redemptor hominis, do którego się odwołujemy, przedstawia Serce Odkupiciela pod aspektem, który moglibyśmy określić jako „obiektywny”, to znaczy nie odnosi się wprost do naszej pozycji w stosunku do Serca Chrystusa, ale wyraża miejsce, które zajmuje ono w wiecznym zamyśle odkupienia. Dla naszego tematu jest szczególnie ważne, że Serce Jednorodzonego Syna, nadobficie wypełnione sprawiedliwością i świętością, jest podobne do źródła, które przelewa tę sprawiedliwość i świętość w serca odkupionych. Szczególne znaczenie ma tutaj obraz przebitego boku (Serca) Jezusa na krzyżu, ukazujący pełnię daru, którego chce On udzielić człowiekowi. Jest to Serce promieniujące miłością, której nie zatrzymuje dla siebie ani nawet dla Ojca, ale zwraca się do wszystkich i wszystkich obejmuje. Jest to uniwersalne promieniowanie, które ukazuje, że Jezus Chrystus jest „sercem świata” jak

15 Por. K. Rahner, Teologia symbolu, w: K. Rahner, Pisma wybrane, tłum. G. Bubel, t. 2, Kraków 2007, s. 249-284.

16 Por. A. Vanhoye, Le ricchezze del Cuore di Cristo, Roma 2011. 
sugestywnie podkreślił Hans Urs von Balthasar ${ }^{17}$. Jest to duchowy i metaforyczny, chociaż niezwykle spójny wyraz tego, co dzisiaj nazywamy chrystocentryzmem. Istota nauczania papieża Jana Pawła II pokrywa się z wizją św. Pawła, drogą teologii klasycznej, zwłaszcza św. Tomaszowi z Akwinu, według której Jezus Chrystus jest Głową, z której członki Ciała otrzymują wszystkie łaski ${ }^{18}$. W ujęciu teologicznym papieża Jana Pawła II otrzymujemy więc sugestię, aby tradycyjną i w wielu przypadkach kluczową teologię Chrystusa jako Głowy połączyć z teologią Jego Serca, pogłębiając w ten sposób jej duchowe znaczenie, a tym samym teologię Serca Jezusa włączyć integralnie do tych aspektów teologii, które szczególnie łączą się z teologią Chrystusa Głowy. Nie bez znaczenia będzie podkreślenie w tym miejscu, że zagadnienie może mieć szczególne znaczenie dla pogłębienia teologii hierarchii i urzędu kościelnego, dzięki czemu mogłyby one zyskać wyraźniejsze związanie z miłością, zgodnie z Augustyńską koncepcją amoris officium ${ }^{19}$.

W nauczaniu Jana Pawła II klasyczna koncepcja Chrystusa - Głowy zostaje ubogacona rysem serca, który dokonuje jej pogłębienia personalistycznego. Jego znaczenie moglibyśmy wyrazić w następujący sposób: odkupienie świata jest rzeczywistością, ponieważ Jezus Chrystus, Syn Boży, pojednał ludzi z Ojcem w nieogarnionej miłości swojego Serca; On, „człowiek Chrystus Jezus” (1 Tm 2, 5), stał się dla nas „mądrością od Boga i sprawiedliwością, i uświęceniem, i odkupieniem" (1 Kor 1, 30). W ten sposób dzięki miłości Jego Serca otrzymujemy sprawiedliwość i uczestniczymy w Jego usynowieniu, w Jego łasce i Jego miłości, doznając przemiany naszego wnętrza za pośrednictwem boskiego daru nowego serca i nowego ducha (por. Ez 36, 28). Miłość Chrystusa przyciąga nas do siebie i wprowadza w tajemnicę udzielającego się nam życia Bożego, którym jest łaska, co dobrze wyraża wezwanie modlitewne: „Serce Jezusa, źródło życia i świętości”. Można więc powiedzieć, że za pośrednictwem swego miłującego Serca Chrystus objawia się nam jako wielki Gest miłości Bożej

17 H. U. von Balthasar, Serce świata, tłum. U. Poprawska, Kraków 2003.

18 Por. Y. Congar, Saint Augustin et le traité scolastique „De gratia Capitis”, „Augustinianum” 20 (1980), s. 79-93.

19 Augustyn, In Ioannis Evangelium tractatus 123, 5: PL 35, 1967. 
udzielającej się darmowo człowiekowi. On sam jest osobowo miłością Bożą, jakby „zagęszczającą się” w Jego Sercu, aby za jego pośrednictwem oblubieńczo objąć wszystkich i wprowadzić ich na drogę zbawienia.

Ludzka pozycja wobec Serca Jezusa zostaje także głębiej oświecona przez przypomnienie przez papieża Jana Pawła II potrzeby jego uniwersalnego „naśladowania”. Podkreśla on w odniesieniu do Kościoła, „ażeby [...] na wzór swego Mistrza, który był «pokorny sercem» (Mt 11, 29), również kierował się pokorą" (nr 4). Zakłada to, że cały Kościół potrzebuje zapatrzenia się w najświętsze Serce Jezusa, które jest wzorem podstawowych cnót nowego prawa, którymi są łagodność i pokora, będąca punktem wyjścia wszystkich cnót oraz źródłem autentyzmu chrześcijańskiego. Nie przypadkiem św. Tomasz z Akwinu podkreślił w swojej teologii nowego prawa - kluczowej kwestii całego jego systemu teologicznego - że jego streszczeniem są właśnie cnoty łagodności i pokory objawione w Sercu Jezusa ${ }^{20}$. On jest nowym człowiekiem, dzięki któremu wszyscy mogą uczestniczyć w Jego odnawiającym dziele, o ile oczywiście także będą szli drogą łagodności i pokory.

\section{Miłość miłosierna}

Encyklika Dives in misericordia papieża Jana Pawła II zawiera dalsze ważne wskazania dotyczące teologii Najświętszego Serca Jezusa w relacji do tajemnicy miłosierdzia Bożego. Stosowne wypowiedzi na ten temat znajdują się w końcowej części encykliki, w której papież mówi o misji Kościoła. Pisze więc tak: „W sposób szczególny zdaje się Kościół wyznawać miłosierdzie Boga i oddawać mu cześć, zwracając się do Chrystusowego Serca; właśnie bowiem zbliżenie do Chrystusa w tajemnicy Jego Serca pozwala nam zatrzymać się w tym niejako centralnym, a zarazem po ludzku najłatwiej dostępnym punkcie objawiania miłosiernej miłości

20 Tomasz z Akwinu, Super Matthaeum XI, 3: „Tota enim lex nova consistit in duobus: in mansuetudine et humilitate. Per mansuetudinem homo ordinatur ad proximum. Unde Ps. CXXXI, v. 1: memento, domine, David, et omnis mansuetudinis eius. Per humilitatem ordinatur ad se, et ad Deum. Is. LXVI, 2: super quem requiescet spiritus meus nisi super quietum et humilem? Unde humilitas facit hominem capacem Dei". 
Ojca, które stanowiło centralną treść mesjańskiego posłannictwa Syna Człowieczego" (nr 13).

Zwrócenie się do Serca Jezusa w życiu Kościoła, jak wskazuje przywołana wypowiedź, nie oznacza więc niczego innego, jak nieustanne i stale pogłębiane praktykowanie kultu tego Serca i inspirowanie się nim w codziennym życiu chrześcijańskim. Jedną z tych inspiracji jest odniesienie do miłosierdzia Bożego w wielorakiej sytuacji człowieka, ponieważ w nim wyraziła się misja zbawcza Jezusa. Papież Jan Paweł II wielokrotnie pokazał w swoich wypowiedziach, czym była dla niego tajemnica Najświętszego Serca Jezusa i jak wpływała na jego życie i na jego wybory. Oczywiście ten wątek jego pobożności osobistej i rozwijanej teologii ulegał stale pogłębieniu i znajdował coraz to nowe formy wyrazu. W tym miejscu pozwólmy sobie na pewną syntezę tego, co nam zaprezentował, zwłaszcza w odniesieniu do miłosierdzia Bożego ${ }^{21}$.

W wypowiedzi papieskiej chodzi o prawdziwy i właściwy kult oddawany Sercu Jezusa, szczególnie w Eucharystii. Kult ten prowadzi do pobożności skoncentrowanej na Chrystusie i na Jego miłości, szczególnie miłości ofiarnej i serdecznej w stosunku do innych; przypomina o konieczności łagodności i pokory we wzajemnych relacjach, o całkowicie szczególnym wymogu życia wewnętrznego oraz - jako jego fundamentalnej dyspozycji - o poświęceniu się Bogu i oddaniu Mu przez miłość wynagradzającą. W zacytowanym tekście papieskim zostało powiedziane, że Serce Jezusa jest ,niejako centralnym, a zarazem po ludzku najłatwiej dostępnym punktem objawiania miłosiernej miłości Ojca". Dzieje się tak dlatego, że tajemnica wcielenia Syna Bożego w najwyższym stopniu zbliżając Boga do świata, ukazuje także w języku wcielenia Jego przymioty i Jego relację zbawczą w stosunku do człowieka. Przez wcielenie tajemnica Boga, pozostając tajemnicą, ukonkretnia się w jakiś sposób na ludzką miarę oraz wyraża w sposób dostępny dla człowieka, zgodnie z wymaganiami jego natury. Dlatego też miłosierdzie Boże objawione we wcieleniu zostaje skonkretyzowane i przyjmuje poniekąd ludzkie rysy, aby mogło zostać rozpoznane i aby budziło zaufanie. W XIX wieku, gdy wyraźnie

${ }^{21}$ Szersze ujęcie zagadnienia w: P. Warchoł, Miłosierny Bóg imiłosierny człowiek. Teologiczna interpretacja miłosierdzia w nauczaniu Jana Pawła II, Niepokalanów 2011. 
odżywała teologia miłosierdzia Bożego, niemiecki teolog Matthias Joseph Scheeben pisał z wielkim wyczuciem tego zagadnienia: „Aby Jego [Boga] miłosierdzie nie było uważane tylko za formalne współczucie, Bóg aby je w pełni objawić - przyjął we wcieleniu ludzkie serce, aby uczynić je tronem swego miłosierdzia"22. Przez wewnętrzny związek z Sercem Jezusa miłosierdzie Boże staje się po prostu faktem w dziejach ludzkich pojętych jako pewna całość oraz w odniesieniu do każdego człowieka, który otwiera się na nie przez wiarę.

Można powiedzieć, że encyklika Dives in misericordia Jana Pawła II odnosi się do faktu, że ludzkie Serce Chrystusa, objawiając miłosierną miłość Ojca, sytuuje się niejako w punkcie przecięcia wszystkich dróg miłości Bożej, od stworzenia świata, tego pierwszego błysku miłości Bożej, aż do śmierci Chrystusa na krzyżu, która ostatecznie zapaliła światła miłości Bożej nad człowiekiem, zwyciężając grzech i śmierć, jak tego potwierdzenie znajdujemy w zmartwychwstaniu Jezusa, które ukazuje zwycięski wymiar miłości Bożej, a tym samym stanowi wypełnienie objawienia miłosierdzia Bożego. Jego Serce spełnia więc funkcję pośredniczącą i w tym pośredniczeniu syntetyzującą w stosunku do zniżającej się łaskawie miłości Ojca. Ta miłość sama w sobie jest niedostępna, ale staje się dostępna dla człowieka we wcieleniu, czyli w człowieku Jezusie Chrystusie i w Jego dziele zbawczym, w sposób szczególny noszącym na sobie i wyrażającym w poszczególnych tajemnicach zbawczych Jezusa miłosierdzie Boga. Zostało już ono w wielu aspektach objawione w Starym Przymierzu, ale potrzebowało wcielenia, aby nabrać konkretnego kształtu i wyrazu historiozbawczego. W dziejach człowieka tajemnica miłosierdzia Bożego w jej wymiarze zbawczym przedłuża się i wyraża za pośrednictwem Kościoła, będącego jej aktualizującym historycznie „miejscem”. Jest to jeden z głównych wątków encykliki Dives in misericordia, który jest ukazywany począwszy od jej punktu drugiego aż do tekstu, który wyżej przypomnieliśmy. Papież Jan Paweł II nie tylko stwierdza fakt, ale również wyjaśnia rację powiązania, które zachodzi między zbliżaniem się do Chrystusa w tajemnicy Jego Serca a wyznawaniem i czczeniem w najwyższym stopniu miłosierdzia Bożego. Chodzi przede wszystkim

22 M. J. Scheeben, Handbuch der theologischen Dogmatik, Bd. 1, Freiburg 1933, s. 719. 
o to, że w języku ludzkim, wychodząc z utrwalonej tradycji i wrażliwości psychologiczno-kulturowej, mówienie o sercu ma zawsze bliski związek z miłością i dobrocią, w której człowiek wyraża się jako duchowa jedność i całość osobowa.

Zbliżanie się w wierze do Chrystusa w tajemnicy Jego Serca jest tym, co w najwyższym stopniu ułatwia wierzącemu bezpośrednie odkrycie Jego miłosierdzia i jego przymiotów oraz realne zagłębienie się w nim w osobistych doświadczeniach; prowadzi nas do odkrycia tego miłosierdzia, które ze swej strony jest wielkim objawieniem miłosierdzia Ojca, czyli tego, że właściwie biorąc Bóg ma Serce. Dlatego czcząc miłosierdzie Boże - miłosierdzie Ojca - patrzymy na obraz Jezusa Chrystusa i czerpiemy z tych źródeł miłosierdzia, którymi są sakramenty, a które wypłynęły z przebitego boku Chrystusa. Jego Serce otwiera nas na wielką pespektywę sakramentalną, którą żyje Kościół i w której miłosierdzie Boże staje się wydarzeniem osobowym i eklezjalnym. Ta perspektywa łączy w sobie także aspekt moralny, który jest nierozdzielnie związany z objawieniem miłosierdzia Bożego - staje się ono najbardziej wyraziste w odniesieniu do grzechu człowieka i w reakcji Bożej na niego.

Kult Serca Jezusa jest zatem najwyższą formą kultu, którą Kościół ma dzisiaj do praktycznego i szerokiego zrealizowania w swojej misji wyznania i czci miłosierdzia Bożego. Dzięki kultowi Serca Jezusa można dokonać wyrazistej, bo chrystologicznej manifestacji i konkretyzacji tego, czym jest miłosierdzie Boże. Ta misja, z drugiej strony, ma fundamentalne znaczenie, aby Kościół mógł faktycznie dopełnić nauczanie II Soboru Watykańskiego, który każe mu stawać się w dziejach coraz wyraźniej i pełniej sakramentem zbawienia, w tym także głosząc miłosierdzie Boże i dokonując jego wcielenia eklezjalnego. Warto zwrócić uwagę, że zagadnienie miłosierdzia Bożego i jego praktycznego przeżywania w Kościele jest szeroko obecne w nauczaniu II Soboru Watykańskiego ${ }^{23}$. Kult Serca Jezusa, zakorzeniający się w Jego sakramentalności osobowej objawionej we wcieleniu, daje pełne podstawy historycznej sakramentalności

23 Por. J. Królikowski, Eklezjalna wizja miłosierdzia. Od Soboru Trydenckiego do „Misericordiae vultus" papieża Franciszka, w: Miłosierny i sprawiedliwy. W kręgu miłosierdzia Bożego, red. P. Łabuda, L. Rojowski, Tarnów 2016, s. 57-72. 
Kościoła, podkreślając zbawcze znaczenie tego wszystkiego, co jest widzialne w Kościele. Należy to mieć na uwadze tym bardziej, że dzisiaj zagadnienie widzialności Kościoła w jej znaczeniu soteriologicznym jest wyraźnie niedoceniane, gdy tymczasem właśnie to, co widzialne, jest narzędziem łaski, a tym samym zbawienia i jedności z Bogiem. To, co widzialne, jest także znakiem i narzędziem miłosierdzia Bożego.

Wypowiedź dotycząca tajemnicy Serca Jezusa z encykliki Dives in misericordia papieża Jana Pawła II jest uroczystym, choć wyrażonym w nieco innym języku potwierdzeniem tego trafnego stwierdzenia, które papież Pius XI zawarł już na początku encykliki Miserentissimus Redemptor o powszechnym wynagrodzeniu Najświętszemu Sercu Jezusa, gdy podkreślił, że „w tej formie kultu [...] zawiera się streszczenie całej religii i norma doskonałego życia chrześcijańskiego, skoro kult ten prowadzi umysły do gruntowniejszego poznania Jezusa Chrystusa oraz skutecznie nakłania dusze do gorętszej względem Niego miłości i dokładniejszego pójścia w Jego ślady"24. Podobne stwierdzenie znajdujemy w wielkiej encyklice Haurietis aquas o kulcie Najświętszego Serca Jezusowego, którą w 1956 roku ogłosił papież Pius XII. Czytamy w niej: „Jeśli bowiem wejrzymy we właściwą naturę tego kultu, to zobaczymy, że stanowi on najwznioślejszy akt religijny, ponieważ wymaga od nas zupełnego i absolutnego poświęcenia naszej woli miłości Boskiego Odkupiciela, miłości, której żywym wyrazem i znakiem jest Jego zranione Serce"25.

Odniesienie tajemnicy Serca Jezusa do tajemnicy miłosierdzia Bożego i zauważenie, że te dwie tajemnice na siebie wskazują i wzajemnie się dopełniają, w znacznym stopniu potwierdza wspomniany już wyżej syntetyzujący charakter kultu Serca Jezusa, podkreślając zarazem, iż kształtuje ono rozmaite aspekty życia chrześcijańskiego i ma wewnętrzny potencjał, by prowadzić je do doskonałości w miłości. Z kolei miłosierdzie Boże odniesione do kultu Serca Jezusa zyskuje konkretyzację inkarnacyjno-paschalną oraz zostaje włączone w tajemnicę zbawczą Kościoła, który nieustannie czerpie z miłosierdzia Bożego i objawia je historycznie.

24 Pius XI, enc. Miserentissimus Redemptor, dz. cyt., s. 73.

25 Pius XII, enc. Haurietis aquas (15 maja 1956 r.), w: Serce Jezus w dokumentach Kościoła, dz. cyt., s. 138. 
Można więc uogólniająco powiedzieć za papieżem Janem Pawłem II: „Najświętsze Serce bogate w miłosierdzie dla wszystkich, którzy pozostają w niewoli grzechu, jest początkiem i fundamentem pokoju i prawdziwej nadziei. [...]Jego przebite Serce [...] jest niewyczerpanym źródłem Boskiej miłości, która przebacza, odradza, przywraca życie"26.

Nie ulega wątpliwości, że papież Jan Paweł II w encyklice Dives in misericordia wyraził wielkie wyznanie wiary w miłosierdzie Boże oraz spójnie wykazał, jak bardzo wpisuje się ono w historyczną misję Kościoła i jak bardzo potrzebuje go dzisiejszy człowiek, ale zarazem pokazał także, że kult Najświętszego Serca Jezusa stanowi najbardziej właściwą drogę, aby urzeczywistniać i kontynuować to wyznanie wiary, a przez nie głosić wielkość miłosierdzia Bożego okazanego w Jezusie Chrystusie i nieustannie okazywanego człowiekowi w Jego Kościele. Wejście w tajemnicę Najświętszego Serca Jezusa pozwala nam w formie powszechnie dostępnej dla ludzi i bliskiej w swoim wyrazie wniknąć w miłosierdzie Boga Ojca, które objawia się w Jego słowach i Jego czynach dokonanych w czasie ziemskiego życia, przede wszystkim w tajemnicy paschalnej Chrystusa, która przez Jego upokorzenie (por. Flp 2, 5-11) w najwyższym stopniu objawia miłosierną miłość Ojca. Ten, który umiłował nas ludzkim Sercem, w tajemnicy paschalnej i za jej pośrednictwem, otworzył człowiekowi dostęp do Serca Ojca i Jego największej miłości, która miłosiernie rezygnuje z siebie na rzecz człowieka. W ludzkim Sercu Chrystusa i za jego pośrednictwem tajemnica paschalna staje się tajemnicą skonkretyzowanego miłosierdzia Boga, który w najwyższym stopniu „rezygnuje” z siebie, aby być ponad wszystko Bogiem dla człowieka, przede wszystkim dla jego zbawienia.

\section{Jedna tajemnica w dwóch odsłonach}

Patrząc w perspektywie teologicznej wyznaczonej przez papieża Jana Pawła II, wydaje się, iż ponad wszelką wątpliwość należy szukać wewnętrznej jedności teologii Najświętszego Serca Jezusa oraz teologii

26 Jan Paweł II, Serce Jezusa bogate w miłosierdzie. Anioł Pański (16 czerwca 1991 r.), w: Serce Jezus w dokumentach Kościoła, dz. cyt., s. 410. 
miłosierdzia Bożego. Jest to tym ważniejsze, że chodzi o zagadnienia, które mają bezpośrednie odniesienie do kultu kościelnego, do pobożności i do duchowości chrześcijańskiej. Jedność ta wyraźnie się zarysowuje, jeśli sięgamy do spójnego łączenia tych zagadnień tajemnicą Jezusa Chrystusa, komplementarnie ujmującą i łączącą tajemnice Jego wcielenia oraz Jego paschy. Jedność ta zyskuje na znaczeniu, jeśli łączymy ją z tajemnicą Kościoła, wyrastającego z tajemnicy wcielenia, który pełni w dziejach misję najściślej związaną z tajemnicą paschalną. Na pewno więc należy w szerszym niż dotychczas stopniu widzieć jedność tajemnic Serca Jezusa i miłosierdzia Bożego, które tylko w tej jedności odpowiadają na duchowe poszukiwania współczesnego człowieka. 


\section{Summary}

\section{Najświętsze Serce Jezusa objawieniem, źródłem i pośrednikiem miłosierdzia Bożego}

Z teologicznego punktu widzenia zasługuje dzisiaj na uwage zagadnienie wzajemnych relacji zachodzących miedzy teologią Najświętszego Serca Jezusa i teologią miłosierdzia Bożego. Uwzględnienia tego zagadnienia domaga się rozwijający się kult miłosierdzia Bożego, który w niejednym przypadku wyraźnie przejmuje elementy tradycyjnie należące do kultu Serca Jezusa. Jakie relacje łączą te dwa rodzaje kultu, może ukazać tylko głębsze wejście w ich teologię. W niniejszym artykule proponuję więc teologiczne spojrzenie na nauczanie papieża św. Jana Pawła II zawarte w encyklikach Redemptor hominis (4 marca 1979) i Dives in misericordia (30 listopada 1980), gdyż w tych ważnych i ciągle aktualnych dokumentach zawarte są bardzo wyraźne i inspirujące wypowiedzi, pozwalające uchwycić relację zachodzącą między teologią Serca Jezusa i teologią miłosierdzia Bożego. Na tej autorytatywnej i głębokiej teologicznie podstawie będzie można ukazać ścisłe relacje zachodzące między odpowiadającymi tym teologiom dwoma rodzajami kultu i ich wzajemne dopełnianie się. Proponowane ujęcie, zakorzenione w nauczaniu św. Jana Pawła II, może stać się drogowskazem do spójnego połączenia tych dwóch rodzajów kultu w ramach pobożności chrześcijańskiej. Rozwijającemu się kultowi miłosierdzia Bożego należy zapewnić łączność z innymi formami kultu. Chodzi o to, by kult miłosierdzia Bożego usytuować w ramach tradycji kultu Kościoła, a tym samym odkryć w nim możliwości duchowe aktualizowania kultu kościelnego i przystosowania go do nowej sytuacji duchowej obecnych czasów.

Słowa kluczowe: Najświętsze Serce Jezusa, miłosierdzie Boże, kult, miłość, duchowość

\section{The Sacred Heart of Jesus as the revelation, source and agent} of the Divine Mercy

From the theological point of view today there is a need of focusing on the question of the mutual relation between the theology of the Sacred Heart of Jesus and the theology of the Divine Mercy. The Issue has to be considered mainly because of the growing veneration of the Divine Mercy, which in many aspects evidently adopts certain elements which traditionally belong to the worship of the Sacred Heart. The connection between these two cults can only be perceived after a profound theological analysis. Therefore, in this item I propose a theological perspective on the teachings of Saint Pope John Paul II, included in encyclicals Redemptor hominis ( $4^{\text {th }}$ March 1979) and Dives in misericordia ( $30^{\text {th }}$ November 1980), since 
these two significant and current documents contain valid and inspiring statements allowing the reader to grasp the relation between the theology of the Sacred Heart and the theology of the Divine Mercy. This authoritative and theologically profound background will indicate explicitly the close connection between the two cults and the respective theologies and how they complement each other. The proposed view deeply rooted in the teachings of Saint John Paul II may constitute a guideline for coherent combination of these two kinds of worship within Christian devotion. The growing cult of the Devine Mercy should be allowed to merge with other types of worship. The intention is to place the cult of the Divine Mercy within the tradition of the Church devotion, and at the same time to discover its hidden spiritual possibilities of the actualisation of the Church cult and adaptation of it to the new spiritual condition of the present times.

Keywords: Sacred Heart of Jesus, Divine Mercy, cult, love, spirituality

\section{Bibliografia}

Augustyn, In Ioannis Evangelium tractatus, PL 35.

Balthasar H. U. von, Serce świata, tłum. U. Poprawska, Kraków 2003.

Battaglia V., Gesù Cristo, luce del mondo. Manuale di cristologia, Roma 2007 (Bibliotheca - Manualia, 4).

Congar Y., Saint Augustin et le traité scolastique „De gratia Capitis”, „Augustinianum” 20 (1980), s. 79-93.

Høystad O. M., Serce. Historia kultury i symbolu, tłum. M. Gołębiewska-Bijak, Warszawa 2011.

Hryniewicz W., W głąb tajemnicy odkupienia. Doniosłość soteriologicznej nauki Jana Pawła II, w: Jan Paweł II, Redemptor hominis. Tekst i komentarze, red. Z. Zdybicka, Lublin 1982, s. 173-195 (Jan Paweł II Naucza, 5).

Jan Paweł II, Encyklika Redemptor hominis.

Jan Paweł II, Encyklika Dives in misericordia.

Jan Paweł II, Kazanie w czasie mszy św. na placu św. Piotra Dar Boży dla naszych czasów (30 kwietnia 2000), 2, „L'Osservatore Romano” 21 (2000) nr 6, s. 25-26.

Królikowski J., Eklezjalna wizja miłosierdzia. Od Soboru Trydenckiego do „Misericordiae vultus" papieża Franciszka, w: Miłosierny i sprawiedliwy. W kręgu miłosierdzia Bożego, red. P. Łabuda, L. Rojowski, Tarnów 2016, s. 57-72.

Margerie B. de, Histoire doctrinale du culte envers le Coeur de Jésus, t. 2: L'amour devenu Lumière(s), Paris 1995.

Rahner K., Spiritualität und Theologie der Kirchenväter, Düsseldorf-Freiburg i. Br. 1999 (Sämtliche Werke, 3).

Rahner K., Pisma wybrane, tłum. G. Bubel, t. 2, Kraków 2007.

Ratzinger J., Jezus z Nazaretu. Studia o chrystologii, tłum. W. Szymona, Lublin 2015 (Opera Omnia, t. VI/2).

Scheeben M. J., Handbuch der theologischen Dogmatik, Bd. 1, Freiburg 1933. 
Serce Jezus w dokumentach Kościoła. Dokumenty Magisterium Kościoła o Najświętszym Sercu Pana Jezusa od Klemensa XIII do Benedykta XVI, zebrał, opracował i wprowadzeniem opatrzył L. Poleszak, Kraków 2006.

Smuniewski C., Święta Faustyna Kowalska - świadek wiary i miłości Najświętszego Serca Jezusa, w: „Świadkowie wiary imiłości Najświętszego Serca Jezusa”. Sympozjum, 14-16 czerwca 2013, red. J. Królikowski, E. Nosiadek, Tuchów 2013, s. 171-193.

Tomasz z Akwinu, Super Matthaeum.

Vanhoye A., Le ricchezze del Cuore di Cristo, Roma 2011.

W misji wynagrodzenia Bogu przez Serce Jezusa. Materiały z sympozjum naukowego poświęconego kultowi Serca Jezusowego, Lublin 2 października 2014 roku, red. J. Wełna, E. Ziemann, Kraków 2015.

Warchoł P., Miłosierny Bóg i miłosierny człowiek. Teologiczna interpretacja miłosierdzia w nauczaniu Jana Pawła II, Niepokalanów 2011. 